\title{
POOR HEALTH AND CONTRAINDICATIONS - THE MOST COMMON BARRIERS TO PHYSICAL ACTIVITY IN POLES AGED 50+
}

\section{ZŁE ZDROWIE I PRZECIWWSKAZANIA LEKARSKIE - JEDNA Z NAJCZĘSTSZYCH BARIER PODEJMOWANIA AKTYWNOŚCI FIZYCZNEJ WŚRÓD POLAKÓW W WIEKU 50+}

\author{
Elżbieta Biernat ${ }^{1(\mathrm{~A}, \mathrm{D}, \mathrm{E}, \mathrm{F})}$, Sonia Buchholtz ${ }^{2(\mathrm{C}, \mathrm{D}, \mathrm{E})}$
}

${ }^{1}$ Department of Tourism, Collegium of World Economy, Warsaw School of Economics, Warsaw, Poland
${ }^{2}$ Department of Economics I, Collegium of Economic Analysis, Warsaw School of Economics, Warsaw, Poland

Authors' contribution Wkład autorów: A. Study design/planning zaplanowanie badań B. Data collection/entry zebranie danych C. Data analysis/statistics dane - analiza i statystyki D. Data interpretation interpretacja danych E. Preparation of manuscript przygotowanie artykułu F. Literature analysis/search wyszukiwanie i analiza literatury G. Funds collection zebranie funduszy

Tables: 2

Figures: 0

References: 32

Submitted: 2017 Jun 30

Accepted: 2017 Aug 08

\section{Summary}

Background. Poor health / medical contraindications are one of the most commonly declared barriers to physical activity (PA). The aim of the study is to do a quantitative assessment of this barrier in adult Poles, with a particular emphasis on incidence and accumulation in different demographic and socio-economic backgrounds. Material and methods. A representative sample of Poles aged $\geq 50$ years, declaring sporadic PA, or none ( 4253 persons) was examined. To assess the frequency of health indications / medical contraindications as the primary barrier to PA, a statistical analysis was done. The impact of individual variables on individual declarations was assessed using logistic regression. Results. Poor health / medical contraindications are the second $(25.0 \%)$ barrier to PA, after the age factor $(26.6 \%)$. The likelihood that bad health is declared in people with lower education increases more than 2 -fold (ceteris paribus) with regard to those with higher education. As for working people, it is more often evidenced (7-times) in those incapable of working than in the retired ones (4 times). Living in rural areas reduces the chances of pointing to a health barrier by $24 \%$. Although the chances of declaring health as the barrier increase with age, in the oldest (with all other indicators ceteris paribus) it is relatively less likely to be identified, which might suggest that the elderly consider age itself as a barrier to activity rather than poor health. Conclusions. It is necessary to improve health education in adult Poles regarding a conscious lifestyle design, understanding diseases and honest self-assessment of one's health. It is essential to be aware of the physiological symptoms of physical effort, the role of PA both in maintaining and improving one's health and supporting treatment. It is particularly essential to involve in the undertaking health professionals, especially doctors, because of their knowledge and social prestige.

Keywords: physical activity, barrier, bad health / medical contraindications, health, Poles, 50+

\section{Streszczenie}

Wprowadzenie. Zły stan zdrowia/przeciwwskazania lekarskie to jedna z najczęściej deklarowanych barier podejmowania aktywności fizycznej (AF). Celem pracy jest ilościowa ocena wskazań tej bariery przez dorosłych Polaków, ze szczególnym uwzględnieniem częstości występowania oraz kumulacji w przekrojach demograficznych i społeczno-ekonomicznych. Materiał i metody. Badano reprezentatywną próbę Polaków w wieku $\geq 50$ lat, deklarujących sporadyczną AF, albo jej brak (4253 osoby). Do oceny częstości wskazań stanu zdrowia/przeciwwskazań lekarskich jako głównej bariery AF zastosowano analizę statystyczna. Wpływ poszczególnych zmiennych na indywidualne deklaracje oceniano za pomocą regresji logistycznej. Wyniki. Zły stan zdrowia/przeciwwskazania lekarskie są drugą $(25,0 \%)$ barierą AF, w kolejności po wieku $(26,6 \%)$. Wśród osób z niższym wykształceniem ryzyko jej deklarowania rośnie ponad 2-krotnie (ceteris paribus) w stosunku do osób z wykształceniem wyższym. W stosunku do pracujących częściej (7-krotnie) dotyczy Polaków niezdolnych do pracy, niż tych na emeryturze (4-krotnie). Zamieszkiwanie obszarów wiejskich obniża szanse na wskazanie bariery zdrowotnej o $24 \%$. Choć szanse wyboru tej bariery rosna z wiekiem, wśród najstarszych występowanie jej (przy wszystkich innych cechach ceteris paribus) jest relatywnie rzadsze, co świadczyć może o tym, że najstarsze grupy uważają za barierę aktywności wiek, a nie złe zdrowie. Wnioski. Konieczna jest prozdrowotna edukacja dorosłych Polaków na temat świadomego projektowania stylu życia, rozumienia choroby i rzetelnej samooceny zdrowia. Niezbędne jest uświadomienie fizjologicznych objawów wysiłku fizycznego, roli AF zarówno w utrzymaniu i poprawie zdrowia, jak i we wspomaganiu leczenia. Z racji wiedzy i pełnionej roli społecznej, nieodzowna jest w tej kwestii pomoc pracowników służby zdrowia (szczególnie lekarzy).

Słowa kluczowe: aktywność fizyczna, bariery, zły stan zdrowia/przeciwwskazania lekarskie, zdrowie, Polacy, 50+

Biernat E, Buchholtz S. Poor health and contraindications - the most common barriers to physical activity in Poles aged 50+. Health Problems of Civilization. 2017; 11(3): 135-141. doi: 10.5114/hpc.2017.70003.

Address for correspondence / Adres korespondencyjny: Elżbieta Biernat, Warsaw School of Economics, al. Niepodległości 162, 02-554 Warsaw, Poland, e-mail: elzbieta.biernat@sgh.waw.pl; phone: +48 225646000

Copyright: (C) 2017 Pope John Paul II State School of Higher Education in Biała Podlaska, Elżbieta Biernat, Sonia Buchholtz. This is an Open Access journal, all articles are distributed under the terms of the Creative Commons Attribution-NonCommercial-ShareAlike 4.0 International (CC BY-NC-SA 4.0) License (http://creativecommons.org/licenses/by-nc-sa/4.0/), allowing third parties to copy and redistribute the material in any medium or format and to remix, transform, and build upon the material, provided the original work is properly cited and states its license. 


\section{Introduction}

Nearly $25 \%$ of all adult Poles lead a completely passive lifestyle, and more than $40 \%$ do take physical exercise, which is however insufficient to maintain their health [1]. Consequently, they are particularly exposed to civilization diseases [2]. Inadequate physical activity (PA) evidenced in Poles means that direct costs of healthcare are high - $€ 219$ million (in 2012), including those associated with breast cancer - $€ 15$ million, colorectal cancer - € 16 million, ischemic heart disease - $€ 47$ million and type II diabetes - $€ 141$ million [3]. It is estimated that, if every other inactive Pole started exercising, it would bring measurable benefits to society: a $6 \%$ lower mortality rate, $14.6 \%$ fewer cardiovascular disease cases, 2200 fewer colorectal cancer cases, 1,500 fewer women with breast cancer, 64 thousand fewer obese people and 190 thousand fewer overweight. It would have saved 440 million zlotys in the health care system [4].

One way to increase PA is to eliminate obstacles that hinder participation in sport / sport recreation. Barriers are strongly negatively correlated with PA levels [5]. Among the most serious - irrespective of the ethnic group - is poor health / health contraindications [6].

In the light of the results by the Eurobarometer [7], illness or disability is the third most often indicated barrier (42\%), after absence of time (20\%) and lack of motivation (20\%), according to EU-28 citizens (13\%). Also $14 \%$ of Poles point to it, slightly more often than other Europeans (13\%).

A PA deficit is most often declared by the elderly ( $25 \%$ aged $\geq 55$ years), who relate it to a disease or disability; [7]. There is compelling epidemiological evidence that poor health and low perception of one's physical abilities are strongly associated with lower PA in older people [5]. The older people become, the fewer exercises they do due to illnesses or bad mood. This trend is consistently noted internationally both in cross-sectional studies [8] and panel studies [9].

The aim of the study is to do a quantitative assessment of poor health as a barrier to PA in adults (50+), with a particular emphasis on incidence and accumulation in demographic and socio-economic demographic backgrounds. Such knowledge can be helpful in supporting actions eliminating the obstacle.

\section{Material and methods}

The conclusions of the following article are based on the results of the study "Participation of Poles in Sports and Recreation" conducted by the Central Statistical Office of Poland in 2012. The study is based on a questionnaire sent to randomly chosen households, which guarantees national representativeness (by weighing), and reliability of implementation. The research sample is limited to the elderly ( $\geq 50$ years - 4773 people) who declare sporadic PA or its absence (4253 people). The Office's questionnaire asked them for one main cause of insufficient activity, by providing 9 possible reasons. The person could choose from, among others, bad health or medical contraindications, financial reasons, lack of companion, lack of free time or insufficient infrastructure. The study was interested in the first of the indicated barriers.

Quantitative tools, i.e. statistical and econometric analyses, are used in the study. The first one is done to assess the frequency of health indicators / medical contraindications as the primary PA barrier. Due to the uniformity of distribution, it is necessary to perform econometric analyses to distinguish the influence of particular variables on individual declarations. For this purpose, logistic regression is used, in which the major indication is the one of bad health / medical contraindications as the main barrier to increasing PA. If the variable equals 1, it indicates bad health, 0 if otherwise. The set of explanatory variables covers a broad spectrum of demographic factors (age, sex) and socioeconomic ones (education, wealth, residence, labour market status). With respect to age and sex, it was considered appropriate to verify the statistical significance of both variables and their interactions, which are intuitively believed to be crucial as indicators to PA barriers. The HosmerLemeshow test confirms the correct specification of the model. The quantitative analyzes were performed using STATA 14 software.

\section{Results}

Most of the analyzed categories, including sex, age or income, are characterized by a relatively even share of poor health / medical contraindications as a major barrier to inadequate PA (Table 1). The exceptions to them are: the amount of money at one's disposal (the more of it, the less frequent the barrier appears), and one's self-assessment of the status on the labour market (inability to work clearly increases the percentage of declarations). 
Table 1. Frequency of ill-health indications as a major barrier for PA

\begin{tabular}{|c|c|c|c|c|c|}
\hline \multicolumn{2}{|c|}{ variable } & \multirow{2}{*}{$\begin{array}{c}\% \\
23.7 \\
\end{array}$} & \multicolumn{2}{|c|}{ variable } & \multirow{2}{*}{$\begin{array}{c}\% \\
24.1 \\
\end{array}$} \\
\hline \multirow{2}{*}{ sex } & man & & \multirow{5}{*}{ income per capita } & Q5 (upper quintile) & \\
\hline & woman & 26.0 & & Q4 & 26.8 \\
\hline \multirow{6}{*}{ age group } & $50-54$ & 14.9 & & Q3 & 25.4 \\
\hline & $55-59$ & 22.7 & & Q2 & 29.9 \\
\hline & $60-64$ & 27.5 & & Q1 (lower quintile) & 23.1 \\
\hline & $65-69$ & 29.9 & \multirow{5}{*}{$\begin{array}{l}\text { the amount of money } \\
\text { at one's disposal }\end{array}$} & can afford a luxury & 10.1 \\
\hline & $70-74$ & 32.0 & & $\begin{array}{l}\text { enough money, do } \\
\text { not need saving }\end{array}$ & 19.1 \\
\hline & 75 and above & 29.4 & & $\begin{array}{c}\text { enough for daily } \\
\text { shopping, saving } \\
\text { necessary for bigger } \\
\text { shopping }\end{array}$ & 22.6 \\
\hline \multirow{4}{*}{ education } & higher & 20.6 & & $\begin{array}{c}\text { living on a budget on } \\
\text { a daily basis }\end{array}$ & 29.4 \\
\hline & secondary & 24.8 & & $\begin{array}{c}\text { not enough for basic } \\
\text { shopping }\end{array}$ & 35.3 \\
\hline & basic vocational & 23.8 & \multirow{6}{*}{$\begin{array}{l}\text { self-assessed status } \\
\text { on the labour market }\end{array}$} & employed & 10.9 \\
\hline & $\begin{array}{c}\text { lower secondary } \\
\text { and below }\end{array}$ & 28.4 & & unemployed & 16.2 \\
\hline \multirow{2}{*}{ place of residence } & city & 27.2 & & pensioner & 32.5 \\
\hline & countryside & 21.5 & & working at home & 16.5 \\
\hline & & & & unable to work & 50.9 \\
\hline & & & & other & 40.0 \\
\hline
\end{tabular}

Notes: $1 . n=4773 ; 2$. Values of some variables may be lower because of some persons refused to provide answers

The results of econometric modelling suggest that demographic characteristics affect the way poor heath is related to low PA (Table 2). For men aged 55-59, the odds of choosing this as a barrier increase by $40 \%$ when compared to the reference group (men 50-54 years), and this trend is visible until the age of 75. In the oldest, such indicators (poor health as a barrier) are relatively less common with all other values being equal (ceteris paribus). For women aged 50-54, the odds of choosing health as the barrier are about 28\% higher than for their male counterparts; however, this tendency quickly breaks down and over the age of 54. Men are more likely to point to health deficit as the barrier to PA.

Socio-economic factors (education, wealth, occupational activity, residence) are even more important for specifying barriers. In short, the lower the education level, the bigger the chance that a person will point to the health barriers - the chances for those with the lowest education level are two times higher than those with higher education. Household per capita income shows a weak negative correlation with the indication of one's health status, with the minimum in the second quintile. More precise conclusions are related to one's economic assessment. Those declaring that they have enough money and do not need to save extra funds indicate that their low PA is due to poor health $60 \%$ more often than those who claim to be living a certain level of luxury. However, in those who do not even have enough for daily shopping, the chances are almost four times higher compared to the reference category. Also, there are some visible differences when one's labour market status is considered. In general, people who are unable to work and permanently unemployed are more likely to point to health barriers. In relation to the employed people, pensioners are more than four times likely to declare a health barrier, and those unable to work - more than seven times. The temporarily unemployed show a much smaller difference, of around 23\%, compared to the working persons. Also, the fact that one lives in rural areas reduces the chances of pointing to health barriers by $24 \%$. 
Table 2. Poor health or contraindications as the main barrier to PA

\begin{tabular}{|c|c|c|c|c|c|c|}
\hline \multicolumn{2}{|r|}{ variable } & \multirow{2}{*}{$\begin{array}{c}\text { odds ratio } \\
1\end{array}$} & \multirow[t]{2}{*}{$\begin{array}{c}\text { standard } \\
\text { error }\end{array}$} & \multirow[t]{2}{*}{ p-value } & \multicolumn{2}{|c|}{$95 \%$ confidence interval } \\
\hline \multirow{2}{*}{$\operatorname{sex}$} & men & & & & & \\
\hline & women & 1.275 & 0.005 & $<0.0001$ & 1.265 & 1.285 \\
\hline \multirow{6}{*}{ age group } & $50-54$ & 1 & & & & \\
\hline & $55-59$ & 1.397 & 0.006 & $<0.0001$ & 1.386 & 1.407 \\
\hline & $60-64$ & 1.457 & 0.006 & $<0.0001$ & 1.446 & 1.469 \\
\hline & $65-69$ & 1.008 & 0.005 & 0.071 & 0.999 & 1.017 \\
\hline & $70-74$ & 1.571 & 0.007 & $<0.0001$ & 1.557 & 1.586 \\
\hline & 75 and above & 0.914 & 0.004 & $<0.0001$ & 0.906 & 0.922 \\
\hline \multirow{6}{*}{$\begin{array}{l}\text { sex age group } \\
\text { (interaction) }\end{array}$} & man of a given age group & 1 & & & & \\
\hline & woman 55-59 & 0.831 & 0.004 & $<0.0001$ & 0.822 & 0.839 \\
\hline & woman $60-64$ & 0.491 & 0.002 & $<0.0001$ & 0.486 & 0.496 \\
\hline & woman 65-69 & 0.820 & 0.005 & $<0.0001$ & 0.811 & 0.829 \\
\hline & woman 70-74 & 0.417 & 0.002 & $<0.0001$ & 0.412 & 0.421 \\
\hline & woman 75 and above & 0.788 & 0.004 & $<0.0001$ & 0.779 & 0.796 \\
\hline \multirow{4}{*}{ education } & higher & 1 & & & & \\
\hline & secondary & 1.261 & 0.003 & $<0.0001$ & 1.255 & 1.268 \\
\hline & basic vocational & 1.371 & 0.004 & $<0.0001$ & 1.363 & 1.379 \\
\hline & Lower secondary and below & 2.027 & 0.006 & $<0.0001$ & 2.015 & 2.039 \\
\hline \multirow{5}{*}{ income per capita } & Q5 (upper quintile) & 1 & & & & \\
\hline & Q4 & 0.922 & 0.002 & $<0.0001$ & 0.918 & 0.926 \\
\hline & Q3 & 0.808 & 0.002 & $<0.0001$ & 0.804 & 0.811 \\
\hline & Q2 & 0.753 & 0.002 & $<0.0001$ & 0.749 & 0.757 \\
\hline & Q1 (lower quintile) & 0.812 & 0.003 & $<0.0001$ & 0.807 & 0.817 \\
\hline \multirow{5}{*}{$\begin{array}{l}\text { amount of money at } \\
\text { one's disposal }\end{array}$} & can afford a luxury & 1 & & & & \\
\hline & enough money, do not need saving & 1.604 & 0.024 & $<0.0001$ & 1.559 & 1.651 \\
\hline & $\begin{array}{l}\text { enough for daily shopping, saving } \\
\text { necessary for bigger shopping }\end{array}$ & 1.928 & 0.028 & $<0.0001$ & 1.874 & 1.984 \\
\hline & living on a budget on a daily basis & 2.697 & 0.039 & $<0.0001$ & 2.621 & 2.775 \\
\hline & not enough for basic shopping & 3.724 & 0.056 & $<0.0001$ & 3.616 & 3.835 \\
\hline \multirow{2}{*}{ place of residence } & city & 1 & & & & \\
\hline & countryside & 0.757 & 0.001 & $<0.0001$ & 0.754 & 0.759 \\
\hline \multirow{6}{*}{$\begin{array}{l}\text { self-rated status on the } \\
\text { labour market }\end{array}$} & employed & 1 & & & & \\
\hline & unemployed & 1.178 & 0.006 & $<0.0001$ & 1.167 & 1.190 \\
\hline & pensioner & 4.346 & 0.010 & $<0.0001$ & 4.326 & 4.366 \\
\hline & working at home & 1.539 & 0.008 & $<0.0001$ & 1.525 & 1.554 \\
\hline & unable to work & 7.131 & 0.043 & $<0.0001$ & 7.047 & 7.216 \\
\hline & other & 4.845 & 0.030 & $<0.0001$ & 4.786 & 4.904 \\
\hline constant & & 0.050 & 0.001 & $<0.0001$ & 0.049 & 0.052 \\
\hline
\end{tabular}

Notes: $1 . \mathrm{n}=4253$; 2 . Hosmer-Lemeshow test to specify the model's accuracy: $\mathrm{p}<0.0001$

\section{Discussion}

Seemingly, the conducted research shows nothing new in relation to what is already known from literature. As in other countries [6], poor health is one of the most frequently declared barriers to PA. In the analyzed population, it is the second reason (25.0\%) after the age factor (26.6\%) reason. As in the Eurobarometer survey (25\%) [7], 26\% of Poles aged $\geq 50$ point to it. As in other countries [6], poor health is a limitation especially for the elderly. According to the CSO [10], it keeps $31.2 \%$ of the people aged $\geq 60$ years from doing sports. The German studies show that the percentage of seniors (72-93 years) pointing to it as a barrier is even higher (57.7\%) [11]. The present study can confirm the findings - groups of the elderly using this argument to justify lack of movement grow with age (18.8\% - 50-59 years, $28.7 \%-60-69$ and $30.7 \%-\geq 70$ years). It is very disturbing because, according to Kocemba [12], in the Polish society bad health, disease or disability often exclude the person from practicing sport almost completely.

Łysak et al. [13] indicate that it is women who are more likely to blame bad health for the lack of activity than men (19.4 vs. 8.7\%) in the Polish population. Reports from other countries are not uniform in this respect [8]. 
Our results show that, for women aged 50-54, the odds of choosing poor health as the barrier are about $28 \%$ higher than for their male counterparts, but this trend rapidly breaks down over the age of 54 and the situation changes, as it is men who are more likely to point to health deficits as a barrier to PA.

For men aged 55-59 years, the odds of choosing this barrier increase by $40 \%$ when compared to 50 -54-yearolds. This trend continues until the age of 75. It should be noted, however, that in the oldest such statements are relatively rare in comparison to all other reasons. This may indicate that for the oldest group of respondents, the barrier to PA is not so much health, but age and all the limitations coming with it, such as difficulty in moving or pain [14], fear of personal safety [15], fatigue [14,16] or anxiety that physical activity can result in falls or fainting [17]. Such fears, which are usually declared by the elderly, make the idea of exercise uncomfortable or even frightening. Even simple activities like walking can bring feelings of frustration [17], which in turn can lead to the belief that PA increases their physical pain and disease symptoms [18].

According to the researchers, such declarations may result from: first, lack of knowledge about the disease (its perception and understanding) [17]; second, lack of knowledge about the role of PA in maintaining and improving health as well as supportive care [19]. They can also indicate that people are unaware about the physiological symptoms of physical activity. For example, many diabetics are unaware of the fact that dyspnoea, an increased heart rate and sweating are normal effects of exercise [17].

Respondents justify the lack of activity by pointing to medical contraindications, although the specialists' opinion on this issue is unequivocal - there is no evidence that PA (except for a few contraindications) is harmful to people's health [20]. It has been shown repeatedly that, if appropriately selected, it is safe, effective and extremely important, both for the elderly with functional limitations [20], for people with chronic diseases [21] and for the disabled [22].

Naturally, educating the public plays an important role, for example, in one's conscious design of a healthy lifestyle, understanding the disease, or the proper self-esteem [23]. According to Murtagh et al. [24], people with poor self-perceived health are more likely to be inactive than those who have a positive view of it. Healthy education depends on many factors, including a socio-economic status. Our study shows that socio-economic conditions are even more important in choosing health as a barrier than demographic determinants. As far as Poles are concerned, the less educated they are, the bigger the risk of such indications (when compared to the more educated ones), as it grows more than 2-fold. Persons unable to work and permanently unemployed are more likely to make such choices. In relation to those working, the choice of health as a barrier is far the biggest, often 7-fold, when it refers to people incapable of work than those who are retired (4 times more often, other indications being equal (ceteris paribus). People living in the countryside are less likely to point to health as a barrier by $24 \%$.

What remains to be raised is the issue of responsibility for health education in society. Many patients point to GPs as the main source of information on healthy lifestyles [25,26]. They expect them to provide it to them but, at the same time, accuse them of insufficient advice on how to combat the barriers [16]. Patients complain of lack of programmes targeted to specific patient groups and unclear instructions on exercise regimens and exercise usefulness [16,21]. In their opinion, few doctors prescribe exercise to patients [27], which might mean that they do not recommend it. This is confirmed indirectly by our results, as only a small percentage of patients engage in exercise on being told to do that by health workers / doctors (4.8\%- aged 50-54; 5.7\% - 55-59 years; 7.9\% - 6064 years; $8.4 \%$ - 65-69 years, $9.8 \% 70-74$ years, $6.4 \%$ - age $75+$ ). Paradoxically, more than $80 \%$ of Poles consider themselves to be health-conscious [28]. According to the Central Statistical Office [10] and Eurobarometer [7], health improvement is the reason to get involved in PA most frequently mentioned by Poles. However, as the Centre for Social Opinion Studies indicates, these declarations are not supported by real-life actions [28].

The question arises why those representing the health care system are not actively involved in recommending $\mathrm{PA}$, as one would expect due to their knowledge. One reason is that the public-funded centres have limited time for one patient (again, there is also evidence that it does not take much time to discuss the benefits of exercise [29]). Another one is that doctors are busy [27] and themselves do not follow an active lifestyle [30]. This is evidenced by the Warsaw study - as many as $52 \%$ of the physicians, $39.4 \%$ of the nurses and $42.2 \%$ of the other medical staff demonstrate low levels of PA (not sufficient to maintain proper health) [30].

\section{Conclusions}

Lack of recommendations or advice on PA during medical visits is a missed opportunity, as during that time patients could overcome the unwillingness to practice and stop justifying their inactivity with poor health / medical contraindications. Physicians' attitude to the issue is important in patients' perception of barriers to disease [26] and in getting patients out of the vicious circle: limiting one's PA, which leads to physical weakness, 
falls, fears, doubts and consequently loss of one's independence and participation in social life [31]. Unfortunately, so far there has been no noticeable behavioural change in this respect demonstrated by the health care system representatives, which is not only a problem in Poland [27]. However, there are several initiatives in the world which provide examples of effective action [32]. They show that newly deployed programmes may affect not only the public but also the commissioners (health professionals engaging in the design of exercise programmes to maintain a high level of PA in their own lives [15]). They show that proper interventions and an increase in PA in seniors effectively reduce their fear of falling [31].

Health professionals' involvement in reducing the barrier to poor health / no exercise due to medical contraindications is essential. A social campaign could start by including a statement "Physical activity on every prescription" in every prescription written by the Polish doctor. That would remind him/her of the need to recommend physical activity to patients.

\section{Disclosure and acknowledgements}

The survey was commissioned and conducted by the Central Statistical Office of Poland.

\section{References:}

1. Biernat E, Buchholtz S. The Regularities in Insufficient Leisure-Time Physical Activity in Poland. Int. J. Environ. Res. Public Health. 2016; 13: 798.

2. Szymborski J, editor. Zdrowie publiczne i polityka ludnościowa. Warszawa: Rządowa Rada Ludnościowa; 2012 (in Polish).

3. The economic cost of physical inactivity in Europe. International Sport and Culture Association/Cebr report. Centre for Economics and Business Research; June, 2015 [cited 2017 Jun 10]. Available from: http://www. friendsofeurope.org/media/uploads/2015/06/The-Economic-Costs-of-Physical-Inactivity-in-EuropeJune-2015.pdf

4. Ocena korzyści społecznych inwestycji w sport w odniesieniu do ponoszonych kosztów. Raport analityczny. Instytut Badań Strukturalnych. Ministerstwo Sportu i Turystyki: Warszawa; 2016 [cited 2017 Jun 10]. Available from: http://ibs.org.pl/app/uploads/2017/01/IBS_Report_03b_2016_pl.pdf (in Polish).

5. Bauman AE, Sallis JF, Dzewaltowski DA, Owen N. Toward a better understanding of the influences on physical activity - The role of determinants, correlates, causal variables, mediators, moderators, and confounders. Am J Prev Med. 2002; 23: 5-14.

6. Grossman MD, Stewart AL. 'You aren't going to get better by just sitting around': physical activity perceptions, motivations, and barriers in adults 75 years of age or older. Am J Geriatr Cardiol. 2003; 12: 33-37.

7. Sport and physical activity. Eurobarometer 2013 [cited 2017 Jun 10]. Available from: http://ec.europa.eu/ public_opinion/archives/ebs/ebs_412_en.pdf

8. Booth ML, Bauman A, Owen N. Perceived barriers to physical activity among older Australians. J Aging Phys Activ. 2002; 10: 271-280.

9. Hirvensalo M, Lampinen P, Rantanen T. Physical exercise in old age: An eight-year follow-up study on involvement, motives, and obstacles among persons age 65-84. J Aging Phys Activ. 1998; 6: 157-168.

10. Uczestnictwo Polaków w sporcie i rekreacji ruchowej w 2012 r. Informacje I opracowania statystyczne. GUS: Warszawa; 2013 (in Polish).

11. Moschny A, Platen P, Klaassen-Mielke R, Trampisch U, Hinrichs T. Barriers to physical activity in older adults in Germany: a cross-sectional study. Int J Behav Nutr Phys Act. 2011; 8: 121-130.

12. Kocemba W. Społeczne zróżnicowanie uczestnictwa w kulturze fizycznej. [In:] Dziubiński Z, Krawczyk Z., editors, Socjologia kultury fizycznej. Warszawa: Wydawnictwa Dydaktyczne; 2012, p. 404-423 (in Polish).

13. Łysak A, Walentukiewicz A, Drabik J, Dąbrowski A, Rowiński R. Aktywność fizyczna i niektóre jej uwarunkowania w populacji seniorów województwa pomorskiego. Hygeia Public Health. 2014; 49(3): 549553 (in Polish).

14. Henchoz Y, Zufferey P, So A. Stages of change, barriers, benefits, and preferences for exercise in RA patients: a cross-sectional study. Scand J Rheumatol. 2013; 42(2): 136-145.

15. McPhail SM, Schippers M, Marshall AL, Waite M, Kuipers P. Perceived barriers and facilitators to increasing physical activity among people with musculoskeletal disorders: a qualitative investigation to inform intervention development. Clin Interv Aging. 2014; 9: 2113-2122.

16. Law RJ, Breslin A, Oliver EJ, Mawn L, Markland DA, Maddison P, et al. Perceptions of the effects of exercise on joint health in rheumatoid arthritis patients. Rheumatology (Oxford). 2010; 49(12): 2444-2451. 
17. Lawton J, Ahmad N, Hanna L, Douglas M, Hallowell N. 'I can't do any serious exercise': barriers to physical activity amongst people of Pakistani and Indian origin with Type 2 diabetes. Health Educ Res. 2006; 21(1): 43-54.

18. Gothe NP, Kendall BJ. Barriers, Motivations, and Preferences for Physical Activity Among Female African American Older Adults. Gerontol Geriatr Med. 2016 Jan-Dec; 2: 2333721416677399.

19. At least five a week: Evidence on the impact of PA and its relationship to health. A report from the Chief Medical Officer. London: Department of Health; 2004.

20. Nied RJ, Franklin B. Promoting and Prescribing Exercise for the Elderly. Am Fam Physician. 2002 Feb 1; 65(3): 419-427.

21. Green BN, Johnson C, Moreaud W. Is physical activity contraindicated for individuals with scoliosis? A systematic literature review. J Chiropr Med. 2009 Mar; 8(1): 25-37.

22. Nelson ME, Rejeski WJ, Blair SN, Duncan PW, Judge JO, King AC, et al. Physical activity and public health in older adults: recommendation from the American College of Sports Medicine and the American Heart Association: Circulation. 2007 Aug 28; 116(9): 1094-105.

23. Ismail H, Wright J, Rhodes P, Small N. Religious beliefs about the causes and treatment of epilepsy. B J Gen Pract. 2005; 55: 26-31.

24. Murtagh EM, Murphy MH, Murphy NM, Woods C, Nevill AM, Lane A. Prevalence and Correlates of Physical Inactivity in Community-Dwelling Older Adults in Ireland PLoS One. 2015; 10(2): e0118293.

25. Bergier B, Bergier J, Kubińska Z. Environmental determinants of participation in tourism and recreation of people with varying degrees of disability. J Toxicol Environ Health A. 2010; 73(17-18):1134-40.

26. Lanhers C, Duclos M, Guttmann A, Coudeyre E, Pereira B, Ouchchane L. General Practitioners' Barriers to Prescribe Physical Activity: The Dark Side of the Cluster Effects on the Physical Activity of Their Type 2 Diabetes Patients. PLOS ONE. 2015; 10(10): e0140429.

27. Zimmerman R. Doctor's Orders: Prescribe Exercise To Patients, Make Physical Activity A Vital Sign. CommonHealth, December 10, 2015 [cited 2017 Jun 10]. Available from: http://www.wbur.org/ commonhealth/2015/12/10/doctors-prescribe-exercise-to-all-patien

28. Polacy o swoim zdrowiu oraz prozdrowotnych zachowaniach i aktywnościach. CBOS; Warszawa; 2012 (in Polish).

29. Kallings LV. Physical activity on prescription. Studies on Physical activity level, adherence and cardiovascular risk factor. Stockholm: Karolinska Instituted; 2008.

30. Biernat E, Poznańska A, Gajewski AK. Is Physical Activity of Medical Personnel a Role Model for Their Patients. Ann Agric Environ Med. 2012; 19(4): 707-710.

31. Zijlstra G, Van Haastregt J, Van Rossum E, Van Eijk JTM, Yardley L, Kempenet G, et al. Interventions to Reduce Fear of Falling in Community-Living Older People: A Systematic Review. J Am Geriat Soc. 2007; 55: $603-615$.

32. Hammond JM, Brodie DA, Bundred PE. Exercise on prescription: guidelines for health Professionals. Health Promot Int. Oxford University Press 1997; 12(1): 33-41. 